\title{
Introduction: Political Theologies of the International-the continued relevance of theology in international relations
}

\author{
Vassilios Paipais ${ }^{1}$
}

Published online: 23 July 2018

(C) Springer Nature Limited 2018

Since the end of the Cold War, the growing talk of a 'clash of civilizations' and the 'return of religion', reflected in the rise of political Islam and the Christian right in the U.S., has become one of the most pervading and controversial features of contemporary world politics (e.g. Kepel 1993; Huntington 1996; Habermas 2002). Since 9/11 and the 'War on Terror', more particularly, the role of religion in shaping global politics has been reappraised calling into question the unrivalled dominance of secularism in public affairs (Wilson 2012; Hurd 2015). Within International Relations (IR), recent debates on post-secularity have explored the implications of the resurgence of religion and a post-secular international system for security, democracy and global governance (e.g. Mavelli and Petito 2014). The models of secularization previously in use (premised on the replacement or 'expropriation' of the religious by the secular) have come increasingly under attack for residing on a misleading opposition between religion and modernity. The emerging paradigm of postsecularity contests the view of religion as a private or violent affair (see Cavanaugh 2009) and calls for a renewed exploration of how religious traditions can and perhaps should contribute to the project of a post-secular democracy and world order (see Barbato and Kratochwil 2009; Butler et al. 2011).

Situated within this wider reassessment of the relation between religion and politics, this special issue takes the discussion forward by deliberately focusing, not primarily on religion per se, but rather on theology. While religion has traditionally been the focus of attention within the post-secular paradigm, studied sociologically

This contribution is an introduction to the special issue 'Political Theologies of the International' pointing to the continued relevance of theology in International Relations.

Vassilios Paipais

vp31@st-andrews.ac.uk

1 School of International Relations, University of St Andrews, Arts Faculty Building, The Scores, St Andrews KY16 9AX, Scotland, UK 
either as an identity marker, a 'thick' element of 'culture' or an affective dimension of transnational civil society, theology is usually treated as an expression of metaphysical dogmatism, a witch's brew, perhaps too tied to mysticism and obscurantism to merit serious consideration. Much as Western thinking has been explicitly grounded in theology for most of its history, dominant strands in modern thought sought to overcome this heritage by offering a naturalist metaphysics rooted in human reason and the hegemony of secular immanentism. This culminated in a host of nineteenth century thinkers (e.g. Hegel, Feuerbach, Marx, Nietzsche) proclaiming the 'death of God', a proclamation that, in turn, led many twentieth century philosophers (e.g. Heidegger, Sartre, Derrida, Foucault, Deleuze) to explore the possibility of purging theological metaphysics from thought, typically identifying the latter with superstition, religious dogmatism and otherworldly expectations. In this respect, both secularism and some of its leading post-secular rejoinders share a postmetaphysical orientation that confronts any possibility of conjoining the study of the political and the theological with suspicion or condescendingly calls for the "translation' of theological ideas into publicly validated equivalents. According to this latter view, the theological story is no longer believed but it carries a 'semantic potential' that can be rehabilitated as an imaginative ethical archive or dialogic/hermeneutic 'resource' (see Habermas 2011; Dallmayr 2010).

Yet, the political and the theological are no longer considered strange bedfellows, if they ever were. Beyond Schmitt's (2006, p. 36) familiar dictum that 'all significant concepts of the modern theory of the state are secularized theological concepts' - which was rather meant as a contribution to a sociology of juridical concepts - there is a burgeoning literature that explores what Lefort (1988) has dubbed 'the permanence of the Theologico-Political'. Debates on the relevance of theology for a reconceptualisation of the political, but also of the political for the renewal of traditional theology, have lately proliferated (e.g. Scott and Cavanaugh 2004; De Vries and Sullivan 2006; Lilla 2007; Elshtain 2008; Gillespie 2008; Taylor 2007; Agamben 2011; Critchley 2012). The field of political theology is now an exploding scholarly domain that has attracted some of the most illustrious thinkers in its ranks. Leading contemporary philosophers and political theorists, such as Giorgio Agamben, Charles Taylor, Jean Elshtain, Simon Critchley, Mark Lilla and Allan Gillespie, have argued that modernity's turn away from theology entailed an implicit (re)turn to forms of theology that continued to be subtly and implicitly informed by specific understandings of the relationship between God, self and the world. Political theology explores the ways the religious and the political have diachronically related to each other and why religious discourses have proved more resilient than many expected (Kirwan 2008). Rather than being, as secular polemicists would complain, a poisonous hangover from pre-modernity that threatens the autonomy of the political, political theology reveals the ever-changing relationship between political community and religious order. In short, political theology focuses on the complex connections between rival conceptions of power and authority, rival sources of sovereignty and legitimacy, and rival models of utopia and salvation.

Conceptually, this emerging theo-political outlook challenges the dominant narrative of Western Enlightenment and, by extension, the political structures and concepts used historically to think about the political and the international. Whereas 
a return to the theological was, historically, the preserve of conservative thinkers, contemporary political theology has been of marked interest to critical thinkers as well (e.g. Agamben 2011; Critchley 2012; Davis et al. 2005; Žizek 2003; Eagleton 2010). The latter, of different colours and hues, see in it a way to challenge what they interpret as Western hegemony, expose conceptual ambiguities and the folly of Enlightenment hubris as well as simply provide new concepts to rethink established ideas, intellectual habits and socio-political structures that have, for so long, seemed given. Similarly, within IR an awareness of the theological-political pedigree of international theory is steadily gaining ground (e.g. Guilhot 2010; Pabst 2012; Troy 2013; Gentry 2013; Rengger 2013; Pasha 2013; Bain 2016; Paipais 2017; Molloy 2017). This is a reminder to modern scholars of IR that the influence of theological ideas in global politics is more pervading and wide-ranging than what many are willing to acknowledge. If the attempt to turn away from religion has, in essence, been a return to certain theologically infused concepts (such as anarchy, sovereignty, natural rights, human dignity or oikonomia), we need to make this return explicit, i.e. to rethink the place and meaning of theological ideas in politics and international relations.

Building on this new exciting development in IR theory and international political thought, this special issue investigates the complex interconnections between international politics and political theology, often obscured both by religious fundamentalisms - typified in the rise of militant Islamism and religious extremismon the one hand, and polemical secularisms encountered in modern sociobiological and Neo-Darwinian scientific circles, on the other. Rather than operating within the secular/post-secular binary, however, the contributing articles highlight the political theological foundations of international theory and politics, explicitly recasting IR as a theo-political discourse. In addition, then, to the 'return to religion', this special issue proposes, more specifically, a return to theology and an investigation of its relevance for international theory and politics. However, just as our understanding of international politics is transformed through the encounter with theological tropes, so too theology (not a monolithic discourse, anyway) does not remain unaffected as this return is a journey of transfiguration for theological thinking as well. Thus, the engagement with theology envisaged here operates on the distinction made by Taylor (2011) in his book The Theological and The Political between 'theology' as the traditional historical discourse on transcendence sustained and sanctioned by the hierarchical institutionalization of historical religions, and the 'theological' as what moves along the interstices of immanence and transcendence in the cracks and fissures of these institutionalized forms challenging both religious dogmatism and the secular culture of disenchantment.

Crucially, the contributions to this special issue propose a new way of studying IR that takes theoretical pluralism seriously and moves beyond modernist dichotomies that tend to impoverish scholarly imagination. Indeed, 'Political Theologies of the International' introduces a cutting-edge approach to the study of the international as the realm in which theology and politics are interrogated as essentially similar activities: 'both are constituted in the production of metaphysical images around which communities are organized' (Scott and Cavanaugh 2004, p. 1). The overarching claim this special issue makes is that all politics has theology embedded 
in it. For example, concrete forms or principles of international political organization, such as sovereignty, anarchy and international society, rest on implicit political theologies about the nature of God, natural law, natural right, utopias and political visions as modern-day eschatologies, etc. If this intuition is true, and we argue that it is, theology is more than a residual or peripheral discourse that can be ignored or bracketed. It is rather an integral, albeit often unconscious, part of the discursive constitution of contemporary accounts of human agency, history, society and political organization across communities and cultural traditions. Not merely, however, as a cultural reservoir of ideas, beliefs and historical habits; but, rather, as an active and protean philosophical, historical and political resource in its own standing that never left the scene but rather continues to challenge our modernist complacencies and stretch our political imagination.

The following papers were put together as part of conversations that began at a series of ISA and BISA panels culminating in a May 2015 International Workshop on 'Political Theologies of the International' jointly sponsored by the School of International Relations at the University of St Andrews and the Russell Trust Development Award. The workshop brought together scholars at the forefront of their research areas from a wide variety of disciplines (political theory, history, theology and IR) to explore the interconnections between theologies, politics and international relations. The below contributions, carefully selected, cover a wide variety of topics ranging from a defence of a 'culturalist' conception of international society based on Burkean theological metaphysics to a theological reading of Hobbesian anarchy that exposes the limitations of mainstream social scientific understandings of the concept; also, from an assessment of Eric Voegelin's contribution to rethinking world order in the context of his conception of a metaxy between immanence and transcendence to an exploration of Sayyid Qutb's theocentric reconstruction of the modern concept and practice of sovereignty; and, finally, from a reappreciation of human nature as a cause of war through a reconsideration of the theological doctrine of original sin to a feminist recasting of Christian realism that offers valuable insights into contemporary issues of international security and the study of terrorism.

The first two papers by Adrian Pabst and William Bain engage with the problematique of the metaphysical presuppositions and political theological assumptions underpinning specific conceptions of international order. Long considered a taboo within a largely secular, post-metaphysical discipline, the question of a 'thicker' order of interpersonal relations that generate cross-border connections (including language, customs, music, art, literary modes, religion) —rather than a 'thin' anarchy, which can only be regulated by formal arrangement such as contract and lawfurnishes the opportunity to critique and rethink dominant versions of international and global order. Pabst as well as Bain question the predominant understanding of anarchy around which the study of the international has been organized in the discipline of IR since its inception. For both scholars, this conception of the international as anarchic has roots in a late medieval and early modern imaginary that rests on a voluntarist and nominalist theology. Medieval nominalists, such as William of Ockham and Marsilius of Padua, argued for the priority of the will over the intellect or reason and claimed that universals, such as humanity, justice or 'redness' (the 
property of being red), are but mental names (nomina) that do not pre-exist (as their rival realists would have it) but only follow after (post-res) the existence of particular entities which are the only ones considered real (Gillespie 2008; Rengger 2013). For Pabst, such a view is politically isomorphic with the image of the absolute sovereign as a 'mortal God' and the artificiality of social arrangements that impose an external order on things within a universe that is originally anarchic and composed of human beings that are not naturally political or social. By contrast, he argues that the work of Edmund Burke exemplifies an alternative conception of the political and the international that treats cultural and social bonds as primary rather than secondary to a foundational social contract or an anarchic inter-state system. What Pabst calls the 'primacy of association' invokes the embeddedness of reciprocal rights and mutual duties-Burke's 'obligations written in the heart'. Burke's political theology and its legacy are seen by Pabst as a fruitful resource to reorient the 'culturalist' argument within the English School to a direction that the secularist prejudices of some of its doyens, like Hedley Bull, John Vincent and later Barry Buzan, have perhaps prematurely cut in the bud contra Martin Wight's more theological proclivities.

Bain's paper shares the same critical reading of the anarchy problematique as Pabst's but explores Hobbes' political theology as an offshoot of a theological tradition that argues against the ontological primacy of association. For Bain, Hobbes is an heir of the nominalist revolution that reads political society as an achievement of 'will and artifice', to use Michael Oakeshott's famous phrase. However, Bain goes even further in his critique of mainstream IR theory's employment of the concept of anarchy to argue that even English School or constructivist critics of the domestic analogy miss something of the artificiality of the idea of an anarchical society when its origination in medieval theological debates is overlooked. If those background theological assumptions are acknowledged, we may come to recognize anarchy not as an objective property of a world composed of independent states but rather as a presupposed metaphysical assumption about the nature of reality and the way in which it is constituted as an object of cognition. For such an image, reality resembles a collection of Leibnizian monads that share no intrinsic associations. In such a world, relatedness and sociability is not a given but a pattern of imposed order mirroring the inscrutability and arbitrariness of an all-mighty God who created the world by a mere act of will. Bain provocatively concludes that, for that matter, IR theorists are no different than fourteenth-century nominalist theologians who had to grapple with the problem of reconciling God's freedom with a regular order of nature, only for the former it involves the no less daunting task of accommodating the freedom of states with a regular international order.

The next two papers by Nicholas Rengger and Mustapha Pasha serve to rehabilitate two figures that have been either unduly neglected or vilified in the history of international political thought, the Austrian-American political philosopher, Eric Voegelin and the Egyptian Islamic theorist and activist, Sayyid Qutb. In Voegelin's case, his idiosyncratic reading of modernity as the battleground of Gnostic political religions, such as Fascism and Communism, was widely perceived as the critique of a political reactionary who used obscure religious references, such as his revamped category of Gnosticism, to attack the culture of liberal modernity (see Lilla 2016). Rengger registers Martin Wight's very friendly reception of Voegelin's ideas and the 
affinities in their thought, especially with regard to their common interest in what used to be considered an ambitious and enormously challenging task-reserved for intellectual giants of the likes of Martin Wight himself and his mentor, Arnold Toynbee-the comparative study of civilizations. For Rengger, Voegelin's significance for the study of the prospects, as well as the pathologies, inherent in projects of world order remains undiminished. This is so because Voegelin does not read the problem of 'order' as an issue within the political community; rather, for him, it is a problem of order for the world as the stage where history and consciousness meet in a variety of articulations. In that respect, as Wight rightly observed, his concern was as much, if not more, with world history as a site of order/disorder, than it was with the state. Furthermore, his adaptation of the Platonic metaxy as the tension between transcendence and immanence that all societies through history try to balance, suppress or manipulate may serve as a promising comparative analytical concept. Yet, Rengger expresses reasonable doubts about the ability of Voegelin's symbolic reading of world history to operate as a comparative tool given its distinct European provenance and, especially, given how derivative his world-historical analysis is from the experience of the medieval sacrum imperium and the Christian faith.

Pasha attempts a similar restorative work that is in some ways even more challenging than resurrecting a neglected intellectual oddity like Voegelin. Sayyid Qutb has not only been the subject of fierce, and perhaps unfair, criticism for being the father of militant Salafi Jihadism but has also suffered in the hands of friendly critics for whom he represented the failures and extremities of Islamic reformism. For Pasha, however, it is Qutb's work that best addresses the limitations of reformist Islamism with its tendencies to rely on the same Western, secular ideas it rebels against. Pasha argues that it is important to understand the fundamentally political orientation of Qutb's thought in order to comprehend the basic distinction in his work between Hakimiyyah (God's sovereignty) and Jahiliyyah (the state of ignorance). Pasha patiently demonstrates, not only how Qutb's theocentric conception of sovereignty contests modern Westphalian understandings of order while simultaneously embracing a modern view on power and religion as a transnational ideology, but also how his political-theological reading of sovereignty presents a radical challenge to established sources of legitimate religious authorities. Qutb's radical project is eventually riddled with contradictions that threaten to upset his fine balance between modernist and Quranic horizons. Yet, Pasha is adamant that Qutb presents a self-subsistent defence of Islam which requires neither apology nor accommodation. His political theology speaks on many registers and refuses to privatize the Islamic faith or render it neutral either through the secular suppression of belief or the anti-modern 'politicisation' of Islamic reformers. Pasha's invaluable contribution here is to show how a this-worldly Islamic political theology may look like with all its tensions and ambivalences.

The last two papers by Vassilios Paipais and Caron Gentry agree on the political significance of Christian virtues such as love and Christian symbols such as the original sin. In so doing, they reveal their common debt in themes traditionally advanced by Christian realism. Paipais revisits human nature as a 'first image' cause of war to uncover a hopeful theological anthropology behind secular anthropological assumptions. He attacks realist prejudices about the inherent wickedness of human 
nature and reductionist sociobiological explanations of its alleged hard-wired conflict-proneness as impoverished secularized versions of Christian anthropological insights grounded in the doctrine of original sin. Itself a fiercely contested dogma, in its Augustinian formulation it was closely connected with a soteriological perspective, that is, a defence of its status as a corollary to the doctrine that all human beings are equally in need of salvation in Jesus Christ. However, its use was never entirely disconnected from purposes of theodicy and Christian apologetics striving to reconcile the coexistence of a benevolent and omnipotent God with the existence of evil and suffering in the world. As a result, both theological and philosophical articulations of the doctrine shared an interest in rationalizing a concept that was rather meant to express humankind's paradoxical and ambiguous condition as both free and bounded. For Paipais, the doctrine's complexity and semantic surplus were eventually suppressed, while its legacy became associated with the explanation of suffering and evil in the world, yet stripped of its salvific eschatological content. What issued from this was anthropological pessimism or evolutionary naturalism that often served as a justification for the imposition of the mythic politics of sovereignty/security as protection from a Hobbesian 'state of nature'. Paipais argues, instead, for a political-theological reading of human nature that resists the temptation to attribute human conflictuality to a fixed and irremediable human malice or, as Paipais aptly remarks, the tendency 'to reduce the paradox of original sin to the parody of man's evil nature'.

Gentry in her paper is inspired by a similar desire to build on Christian realist insights on the human condition. Yet, her focus is not on sin and hope, but rather on love and hospitality. The patriarch of Christian realism, Reinhold Niebuhr, has been perhaps rightfully chastised for paying scant attention to love as a political virtue and for emphasizing 'man's' destructive tendencies over his creative ones. The use of gendered language here is not accidental as Gentry thinks that Niebuhr was largely driven by a masculinist perspective that underestimated Christian realism's own existential insight about the centrality of anxiety in Christian life authorizing both destructive and creative responses to human insecurity. Gentry offers a feminist reworking of the Christian realist analytics of anxiety by emphasizing the creative resources that a feminist theology of vulnerability, love and forgiveness may unleash. For Gentry, the Christian virtue of agape is the true meaning of the imago Dei, human beings' God-given ability to respond creatively to the human condition of fragility and finitude by embracing vulnerability as an act of faith and rejecting the dream of total security as idolatrous power-seeking. Gentry's legitimate insight is that if such a Christian realism chastened by a feminist perspective is endogenized, the current anxious counter-terrorist strategies will be revealed for what they are: not only a betrayal of humanity's capacity for creative responses to insecurity based on hospitality and love, but also a self-defeating adherence to conventional epistemic frames and practices that fuel the cycle of violence, insecurity, hatred and fear or what Girard (1977) described as the perpetuation of the vicious circle of sacrificial, mimetic violence.

Ultimately, 'Political Theologies of the International' aims to transcend traditional disciplinary boundaries and transform our understanding of global politics. Indeed, it argues for an alternative way of investigating the theory, history and 
practice of international relations, one that is consciously critical, interdisciplinary, pluralist and wide-ranging. As such, it challenges the boundaries of what constitutes legitimate research in IR adding to the different ways its subject matter can be approached. We are convinced that in an increasingly globalized, post-secular and post-Western world, the investigation of political theologies underpinning international politics may serve as a global research agenda bringing together diverse theoretical and disciplinary perspectives, and cultural practices in the global field of IR. Indeed, a genuinely pluralist research framework cannot afford ignoring alternative methodologies that take faith, religion and theology seriously. Especially in our current predicament, studying the close interrelationship between religious ideas, perceptions of the sacred and metaphysical commitments around which political communities are constituted may not only enhance our understanding of global politics and processes that operate on hidden political theologies. It can also offer a convincing argument for the possibility of a rapprochement between modernity's arch-enemies: science and religion, reason and faith, philosophy and theology.

\section{References}

Agamben, Giorgio. 2011. The Kingdom and the Glory: For a Theological Genealogy of Economy and Government. Stanford, CA: Stanford University Press.

Bain, William (ed.). 2016. Medieval Foundations of International Relations. Abingdon, NY: Routledge.

Barbato, Mariano, and Friedrich Kratochwil. 2009. Towards a Post-secular Political Order? European Political Science Review 1 (3): 317-340.

Butler, Judith, Jürgen Habermas, Charles Taylor, and Cornel West. 2011. The Power of Religion in the Public Sphere. Columbia: Columbia University Press.

Cavanaugh, T.William. 2009. The Myth of Religious Violence. Oxford: Oxford University Press.

Critchley, Simon. 2012. The Faith of the Faithless: Experiments in Political Theology. New York: Verso.

Dallmayr, Fred. 2010. Integral Pluralism: Beyond Culture Wars. Lexington, KY: University of Kentucky Press.

Davis, Creston, John Milbank, and Slavoj Žižek (eds.). 2005. Theology and the Political: The New Debate. London: Duke University Press.

De Vries, Hent, and E.Lawrence Sullivan (eds.). 2006. Political Theologies: Public Religions in a Postsecular World. New York: Fordham University Press.

Eagleton, Terry. 2010. Reason, Faith and Revolution: Reflections on the God Debate. New Haven: Yale University Press.

Elshtain, Jean-Bethke. 2008. Sovereignty: God, State and Self. New York: Basic Books.

Gentry, Caron. 2013. Offering Hospitality: Questioning Christian Approaches to War. South Bend: University of Notre Dame Press.

Gillespie, Allan. 2008. The Theological Origins of Modernity. Chicago: The University of Chicago Press.

Girard, Rene. 1977. Violence and the Sacred, trans. Patrick Gregory, Baltimore: The John Hopkins University.

Guilhot, Nicholas. 2010. American Katechon: When Political Theology Became International Relations Theory. Constellations 17 (2): 224-253.

Habermas, Jürgen. 2011. 'The Political': The Rational Meaning of a Questionable Inheritance of Political Theology'. In The Power of Religion in the Public Sphere, ed. J. Butler et al. Columbia: Columbia University Press.

Habermas, ürgen. 2002. Religion and Rationality: Essays on Reason, God, and Modernity. In Transcendence from Within, Transcendence in this World, ed. Eduardo Mendieta. Cambridge: Polity Press.

Huntington, Samuel. 1996. The Clash of Civilizations and the Remaking of World Order. London: Penguin. 
Hurd, Shakman Elizabeth. 2015. Beyond Religious Freedom: The New Global Politics of Religion. Princeton, NJ: Princeton University Press.

Kepel, Gilles. 1993. The Revenge of God: The Resurgence of Islam, Christianity, and Judaism in the Modern World, trans. Alan Braley, Cambridge: Polity Press.

Kirwan, Michael. 2008. Political Theology: An Introduction. Minneapolis: Augsburg Fortress.

Lefort, Claude. 1988. 'The Permanence of the Theologico-Political?' In Democracy and Political Theory, ed. David Macey, pp. 213-225. Cambridge: Polity Press.

Lilla, Mark. 2016. The Shipwrecked Mind: On Political Reaction. New York: New York Review of Books.

Lilla, Mark. 2007. The Stillborn God: Religion, Politics and the Modern West,. New York: Vintage Books.

Mavelli, Luca, and Fabio Petito (eds.). 2014. Towards a Postsecular International Politics: New Forms of Community, Identity, and Power. New York: Palgrave Macmillan.

Molloy, Sean. 2017. Kant's International Relations: The Political Theology of Perpetual Peace. Michigan: University of Michigan Press.

Pabst, Adrian. 2012. Realism Beyond Secular Reason: Religion and the Revival of Grand Theory in IR. Review of International Studies 38 (5): 995-1017.

Paipais, Vassilios. 2017. Political Ontology and International Political Thought: Voiding a Pluralist World. Basingstoke: Palgrave Macmillan.

Pasha, K.Mustapha. 2013. Nihilism and the Otherness of Islam. Millennium 42 (1): 177-197.

Rengger, Nicholas. 2013. On Theology and International Relations: World Politics Beyond the Empty Sky. International Relations 27 (2): 141-157.

Schmitt, Carl. 2006. Political Theology: Four Chapter on the Concept of Sovereignty, trans. George Schwab, Chicago: The University of Chicago Press.

Scott, Peter, and T.William Cavanaugh (eds.). 2004. The Blackwell Companion to Political Theology. Malden: Blackwell Publishing.

Taylor, Charles. 2007. A Secular Age. London: Belknap Harvard University Press.

Taylor, L.Mark. 2011. The Theological and the Political: On the Weight of the World. Minneapolis: Fortress Press.

Troy, Jodok (ed.). 2013. Religion and the Realist Tradition: From Political Theology to International Relations Theory and Back. London: Routledge.

Wilson, Erin. 2012. After Secularism: Rethinking Religion in Global Politics. Basingstoke: Palgrave Macmillan.

Žižek, Slavoj. 2003. The Puppet and the Dwarf: The Perverse Core of Christianity. Cambridge, MA: MIT Press.

Vassilios Paipais is a Lecturer in International Relations at the University of St Andrews, Scotland. He writes on International Relations theory, political theory and political theology. He is the author of Political Ontology and International Political Thought: Voiding a Pluralist World (Basingstoke: Plagrave, 2017). 